\title{
Transforma-se o amador na coisa amada.....
}

Maria Helena Serôdio

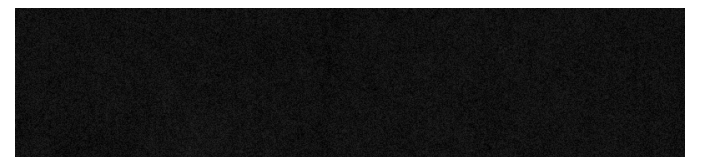

RUI PINA COELHO

\section{JÁ PASSARAM QUANTOS \\ ANOS PARGUNTOU AlF E OUTROS TEXTOS \\ (A IRRISÃO DAS FLORAS/ FALL COLLACTIONV AINDA ASSIM)}

Rui Pina Coelho, Já passaram quantos anos, perguntou ele, e outros textos ( $A$ irrisão das flores; Fall Collection; Ainda assim), Vila Nova de Famalicão, Húmus, Publicações CCT/TEP, Colecção Teatro Não é Literatura, 2013, 162 pp.

0 título, a que aqui deitei mão, cita um verso camoniano bem conhecido - evocando Petrarca, aliás - que, embora vindo da escrita de um tempo já longínquo, faz ainda sentido e oferece a plena espessura de uma coisa vivida.

É de amor, de Eros, que fala Camões, como sabemos, mas julgo poder transferir este verso, e esse sentido do amor, que transfigura, para um outro campo: o do leitor que se faz escritor. Porque a verdade é que continua a reportar-se, na cena da leitura e da escrita, a um idêntico deslizamento de sentidos e de gestos que opera por uma alquimia especial de atracção e identificação: instala-se o gosto, avança a interpelação, cria-se o lugar da fala própria. Que não deixa, como é obvio, de provar que a cultura e as artes são feitas destes "transbordamentos", de que fala Jean-Pierre Sarrazac quando se refere ao "drama na vida" (2002: 229), mas de que falou também, muito antes, T. S. Eliot quando analisou a relação entre 0 talento individual e a tradição (1983 [1920])

Rui Pina Coelho (RPC) é, de há muito, um leitor entusiasta de textos para teatro e tradutor de peças recentes (neste campo, a quatro mãos, com a Ana Raquel Fernandes). É um conhecido crítico da cena teatral, investigador atento às dramaturgias contemporâneas e professor enamorado pelo contacto vivo com as novas gerações (de futuros actores e críticos). E conhecemos agora também a sua valência de dramaturgo, que, aliás, já vinha fazendo caminho em pequenas aventuras, peças curtas e breves apresentações públicas.

É, então, sobre essa nova figuração - ou melhor, transfiguração - que gostaria de deixar aqui algumas breves notas. 0 tópico é, portanto, Já passaram quantos anos, perguntou ele...

0 ponto de partida terá sido Look Back in Anger, de John Osborne, que, em 1956, iniciou e cunhou o novo drama do pós-guerra inglês e que em Portugal se fez em palco com títulos diferentes como se poderá perceber na consulta da CETbase ${ }^{1}$ : 0 tempo e a ira (em 1967 e 1968 na tradução de José Palla e Carmo, respectivamente pelo Teatro Experimental do Porto e pelo Teatro Experimental de Cascais), 0 tempo da ira (pela Companhia de Teatro de Braga, em 1992) e Dá raiva olhar para trás... (com tradução de Gustavo Rubim para a Companhia de Teatro do Chiado, em 1996).

Aliás, foi sobre essa matéria - e a sua avaliação de encontro a questões culturais, políticas e artísticas - que RPC fez a sua tese de doutoramento, com um título de "inspiração narrativa", por ser tão longo, explícito e curioso: Dias dificeis: A representação da violência na dramaturgia britânica de matriz realista do pós-Segunda Guerra Mundial (1951-1967) 2 .

Em aparte, e só por essa circunstância, vale a pena insistir no facto de que o estudo - sério, aprofundado, interrogativo - não inibe, por si próprio, a criatividade, nem retira o gosto pela interpelação criativa, como, por vezes, o preconceito anti-culturalista pretende advogar. E ai está a escrita de RPC para provar isso mesmo.

Na tese, que apresentou, procedeu à análise dos modos de representação artística da violência no teatro inglês 'http://ww3.fl.ul.pt// CETbase/ 

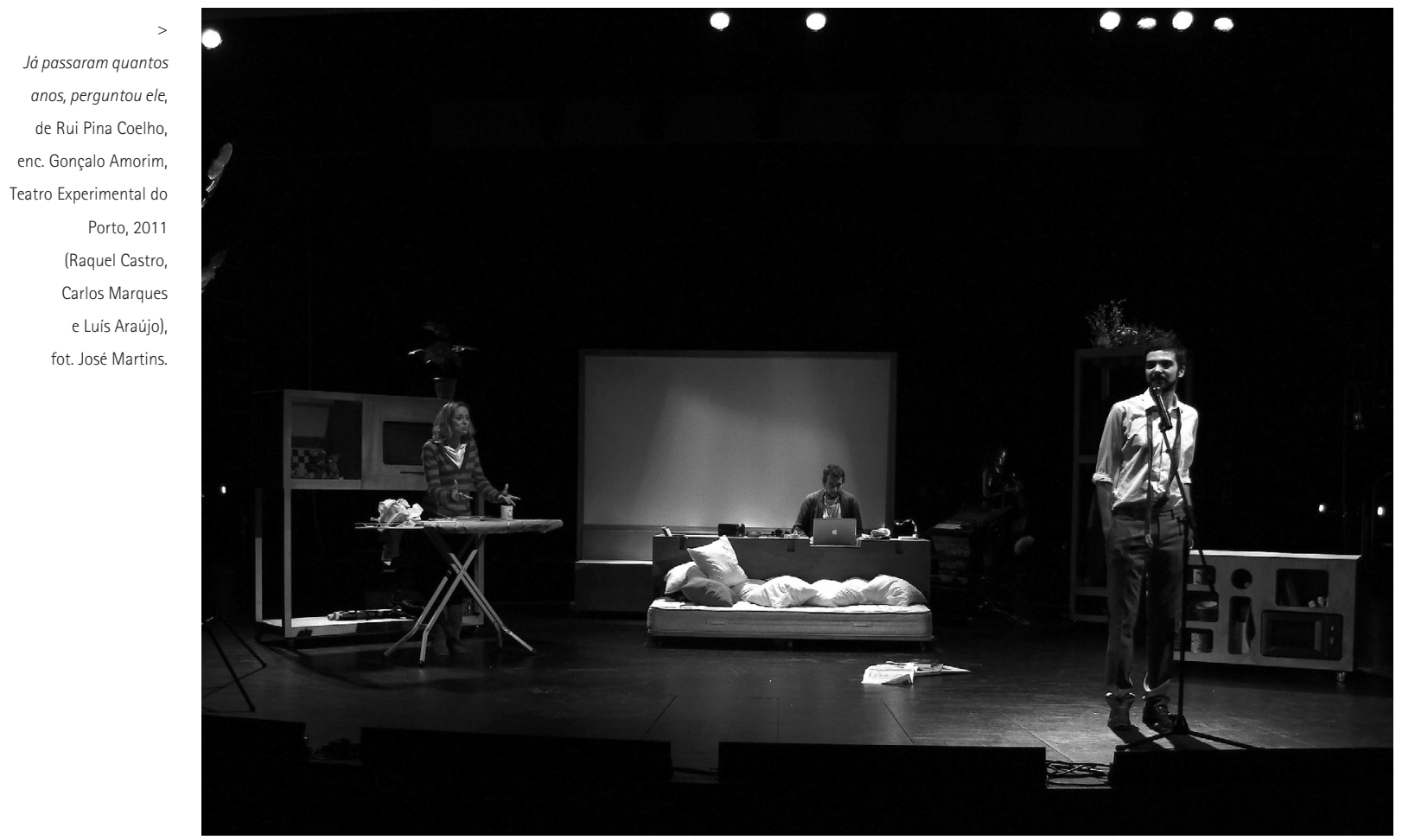

do pós-Segunda Guerra Mundial, partindo de um levantamento exaustivo dos textos dramáticos em que se pode identificar esta temática, mas ponderando igualmente a relação entre essa representação e a sua transposição cénica, e discutindo ainda as formas possiveis de figuração da violência noutros campos artísticos, como são os casos do cinema e das artes plásticas, por exemplo. Restringiu ainda, de modo pertinente, o universo dramático a estudar àquele que trabalha a violência no âmbito da matriz realista e procedeu ao estabelecimento das diferentes tipologias que enformam os textos que analisou. E fê-lo de uma forma rigorosa e num estilo cativante.

No conjunto das peças reunidas no volume, que o TEP agora lançou, pressentimos uma competência de escrita que, desassombradamente, se afirma a partir de um ponto de vista geracional, dando voz e "corpo" a jovens artistas que trabalham no teatro e o entendem como uma prática holística: da aprendizagem da escrita à leitura e prática cénica e, em todos os niveis, procurando a voz, o corpo, o ritmo e os afectos de quem se revê nos problemas de muitos. $E_{1}$ entre esses muitos, está o jovem licenciado (às vezes já Mestre ou mesmo Doutorado) que vê fecharemse à sua frente as portas de emprego para as quais se preparou com esforço e dedicação durante anos.

A peça maior deste volume - Já passaram quantos anos, perguntou ele... - recupera claramente algumas dessas problemáticas referidas ao pós-guerra, mas incorpora já a consequência das derivas económicas e sociais que entretanto avançaram para um grau mais sofisticado de exploração e se instituíram, naturalmente, também entre nós. Essa mais radical exposição às condições de instabilidade e a uma quase extrema declaração de impossibilidade de futuro (no future) para os mais jovens, parece ajustar-se melhor à opção dramatúrgica do autor que apresenta uma composição mais livre, fluindo ao ritmo trepidante das músicas e canções anglo-americanas que invadem o espaço da cena e que parecem recobrir a zoeira de sentidos, que acompanha esse aceleramento, marcada pela de impotência e desânimo.

Não falta, de facto, nesta peça uma maior consciência de um desabar de esperanças de tonalidade apocalíptica, que parece concretizar-se com as repetidas "ameaças" de um fim de mundo que a internet vai "generosamente" anunciando a partir de todas as pragas e infortúnios que ocorrem no planeta Terra: asteróides em rota de colisão com a terra, pássaros e peixes que aparecem mortos às centenas... Prolonga, é certo, uma visão milenarista que já vem do passado, em geral, até porque é razão e consequência da capacidade humana de lembrar o passado e pensar o futuro, só que o faz hoje a partir de meios mais sofisticados e que têm uma capacidade de penetração acrescida, quase viral. Não é de excluir que a insistência nesse processo de pensar o futuro funcione não apenas para exorcizar medos apocalípticos, mas também para os redireccionar para questões que ultrapassam muitas vezes a possibilidade de actuação humana, e, assim, distraindonos da real possibilidade de "fazermos" - ou ajudarmos a fazer - o nosso futuro.

0 título da peça "cita" uma pergunta: Já passaram quantos anos, perguntou ele... Pode ser aquela frase, muitas vezes repetida por amigos e familiares quando se reencontram, esperada ou inesperadamente. Fazem-no porque querem, de facto, saber o que se passou entretanto: "Revisão da vida vivida", escreveria, provavelmente, uma professora no sumário da aula que estudaria esse tempo e esse lugar de vida na conversa entre amigos. Mas é

também importante atender à notação introduzida pelas duas últimas palavras do título - "perguntou ele" -, uma vez que, em si, elas asseguram uma possivel intervenção do "repórter", ou do "narrador", dialogando assim com a matéria jornalística e/ou dramática, ou seja, integrandose no que Sarrazac diz ser o "drama na vida", extensivo ao nosso tempo e às novas gerações.

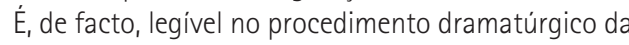




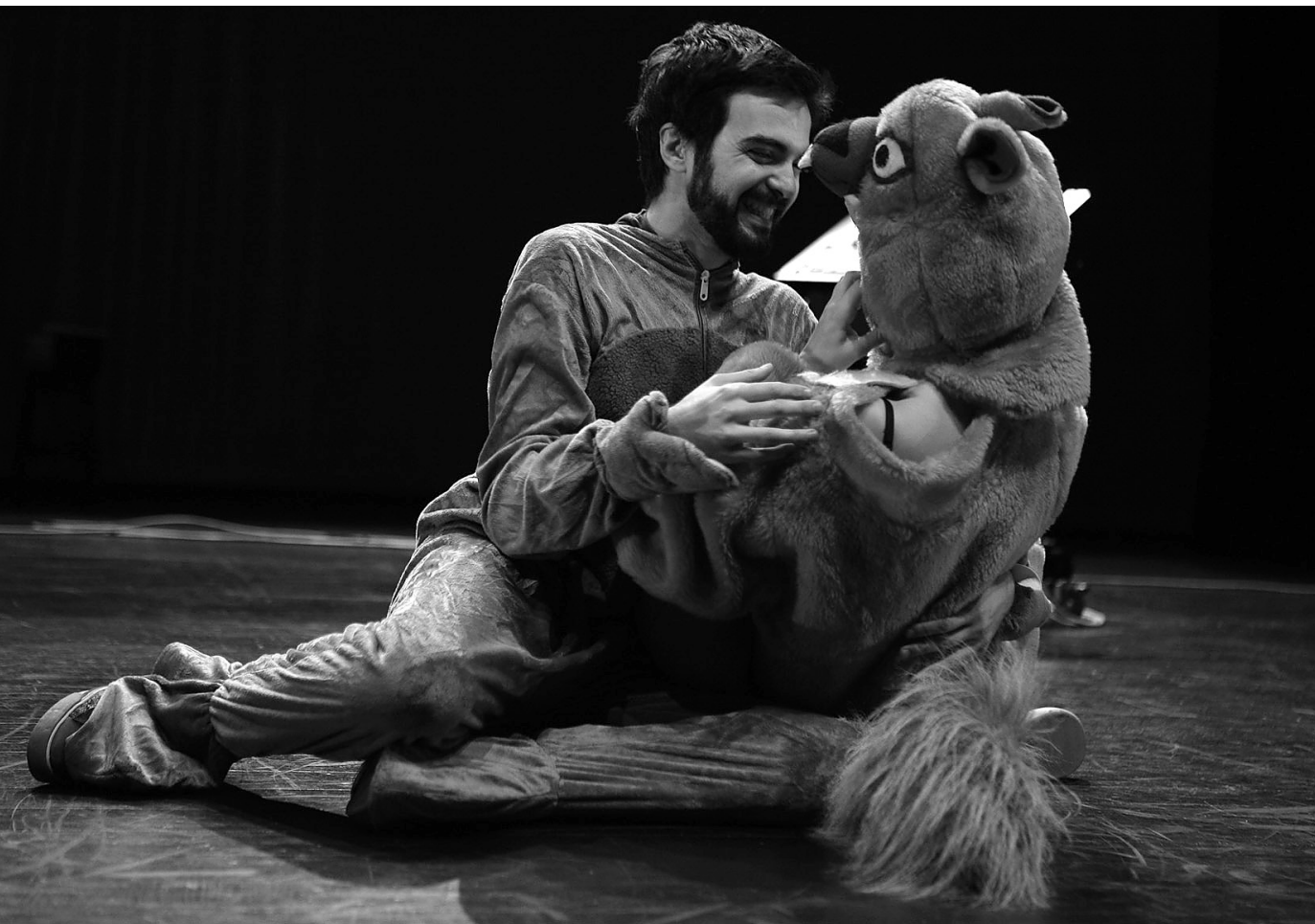

peça de RPC, a rapsodização de que fala Sarrazac (2002: 229-231), ao fazer convergir esta sua "recusa do 'belo animal' aristotélico" com uma opção pela irregularidade, que oferece, na sua gramática textual, um "caleidoscópio dos modos dramático, épico e lírico [...], junção de formas teatrais e extrateatrais, formando o mosaico de uma escrita resultante de uma montagem dinâmica; passagem de uma voz narradora e interrogante", desdobramento "de uma subjectividade alternadamente dramática e épica (ou visionária)". (Ibidem: 229-230). É assim que,

constantemente, o diálogo é interrompido por momentos musicais tanto "ao vivo", com uma das personagens a cantar (o caso de Helena que canta Why Should I Care, de John Addison ${ }^{3}$ ), como na irrupção da música quando ligam a aparelhagem - ou os headphones - para ouvir/mos Sex Pistols, Lou Reed, Baden Powell, The Clash e Talking Heads ou REM. Mas outras falas vêm ainda compor esta "manta de retalhos", como palavras trazidas de Tchekov - na citação inicial de uma frase de Tusenbach, retirada de As três irmãs - ou o que podem ser livros / recomendações para quem se quer preparar para uma entrevista de emprego. Este é, porventura, o "coração destroçado" da vida que se retrata nesta peça: aprender a humildade mais auto-punitiva, anular por completo o sonho e a vontade de afirmar um "eu" como força criativa, mergulhar no desastre que é a vida. E isso nem sequer referido a um radical existencialismo, mas sim num protocolo de real aceitação da condição de sobre-explorado.

\section{$\S \S \S$}

A publicação desta peça ultrapassa, porém, o gesto singular de dar à estampa uma peça (ou um conjunto de peças), para se afirmar antes como um dos aspectos visiveis da renovação do Teatro Experimental do Porto. A nova direcção artística - de Gonçalo Amorim - vê, assim, possível o retomar de uma importante tradição cultural que António
Pedro assumiu logo no início da sua actuação, em 1956, quando iniciava a primeira colecção de textos do Círculo de Cultura Teatral / Teatro Experimental do Porto (CCT/TEP) com a publicação de Macbeth, de Shakespeare, na tradução do próprio António Pedro, a acompanhar a estreia desse espectáculo em Maio de 1956. Já tinham publicado outros livros, mas esse projectava uma continuidade, que, entretanto, infelizmente, foi interrompida.

Na abertura deste volume, Júlio Gago - como Presidente do CCT/TEP - relembra o caminho percorrido, resume algumas das expectativas que acompanham esta nova publicação, e sublinha o contra-ciclo (de anti-cultura) em que o CCT/TEP reafirma a sua presença, comprovando, assim, a sua resiliência:

Num tempo de novas e grandes transformações, como o que agora estamos vivendo na instituição [...] será a altura para o lançamento de uma nova colecção, herdeira da anterior mas com a autonomia necessária que corresponda a um novo salto histórico da nossa afirmação. [...] Apesar da crise que se abate sobre o Povo Português, em que a Cultura volta a ser violentamente menosprezada, esperamos o vosso aplauso, leitores, para estas edições, que nos permitam prosseguir. (p. 12)

\section{Referências bibliográficas}

ELIOT, T.S. (1983), "Tradition and Individual Talent [1920]", in The Sacred Wood: Essays on Poetry and Criticism, Londres \& Nova lorque, Methuen.

SARRAZAC, Jean-Pierre (2002), o futuro do drama [ed. francesa 1999], trad. Alexandra Moreira da Silva, Porto, Campo das Letras. 